\title{
1 Biohydrogen production from waste bread in a continuous stirred tank
}

2

7 Abstract: Biohydrogen production from waste bread in a continuous stirred tank

$9 \mathrm{H}_{2}$-producing plant was assumed to be 2 ton waste bread per day with lifetime of 10

10 years. Aspen Plus was used to simulate the mass and energy balance of the plant. The

11 total capital investment (TCI), total annual production cost (TAPC) and annual revenue

12 of the plant were USD931020, USD299746/year and USD639920/year, respectively.

13 The unit hydrogen production cost was USD1.34/m $\mathrm{m}^{3} \mathrm{H}_{2}$ (or USD14.89/kg $\mathrm{H}_{2}$ ). The

14 payback period and net present value (NPV) of the plant were 4.8 years and

15 USD1266654, respectively. Hydrogen price and operators cost were the most important

16 variables on the NPV. It was concluded that biohydrogen production from waste bread

17 in the CSTR was feasible for practical application.

18 Abstract: biohydrogen production; continuous stirred tank reactor; economic analysis;

\footnotetext{
* Corresponding authors: Jun-Hong Tang, Tel.: +86 13738020870; E-mail address: dr_tjh@163.com
} 
1 waste bread

2

\section{1. Introduction}

4 Due to the environmental pollution and depletion of the fossil fuel, it is urgent to look

5 for the alternative energy in the near future (Turner, 2004). Hydrogen is widely regarded

6 as one of the most important energy carriers because it is clean and renewable (Show et

7 al., 2012). At present, hydrogen is mainly produced from fossil raw materials (such as

8 natural gas), and therefore could not solve the problem of environmental deterioration

9 and energy crisis (Acar and Dincer, 2015). Biological hydrogen production, which could

10 use organic raw material as substrate, seems to be an attractive solution (Wake, 2012;

11 Han et al., 2016a). There are mainly two ways for biological hydrogen production: dark

12 fermentation and photo fermentation (Kim et al., 2010). Photo fermentation seems less

13 attractive than dark fermentation because it would encounter the problem of light

14 limitation (Logan et al., 2002). However, dark fermentative hydrogen production is

15 difficult to realize for practical application due to the high unit hydrogen production

16 cost. Using organic waste (such as waste bread) as feedstock for dark fermentative

17 hydrogen production is considered to be a promising way (Van-Ginkel et al., 2005; Chu

18 and Majumdar, 2012).

19 Waste bread is a major food waste in the world. It is reported that around 1.5 million 
1 tons of waste bread could be produced annually in the China alone (Han et al., 2016b).

2 Waste bread is regarded as an attractive substrate for biohydrogen production because it

3 contains a large amount of starch and protein (De Gioannis et al., 2013). However, the

4 nutrients need to be hydrolyzed into glucose and free amino nitrogen (FAN) prior to be

5 used by $\mathrm{H}_{2}$-producing microorganisms, and which is regarded as the limited step for

6 biohydrogen production (Kim et al., 2011). In the previous study, a novel bioprocess

7 combining solid state fermentation (SSF) and dark fermentation for hydrogen

8 production from waste bread has been successfully developed (Han et al., 2016b).

9 Aspergillus awamori and Aspergillus oryzae were utilized to generate complex enzymes

10 (glucoamylase and protease) from waste bread via SSF. The complex enzymes were

11 then used to hydrolyze the waste bread to generate the liquid waste bread hydrolysate

12 which was utilized as substrate for subsequent biohydrogen production. The proposed

13 combined bioprocess has been proved to effectively accelerate the hydrolysis speed,

14 improve the nutrients conversion rate and increase the biohydrogen yield (Han et al.,

15 2015b). In light of the above technological analysis, the purpose of the present work

16 was to assess the techno-economic feasibility of biohydrogen production from waste

17 bread in the CSTR. 
12.1 Description of biohydrogen production from waste bread in the CSTR

2 Fig. 1 showed the description of biohydrogen production from waste bread in the CSTR.

3 The government was responsible for the collection and transportation of waste bread

4 (Lam et al., 2014). The composition of the waste bread was summarized in the previous

5 study (Han et al., 2016b). The collected waste bread was stored in the E1 and milled

6 into smaller size with water in the E2. The pretreated waste bread was then transferred

7 in the E3 where glucoamylase and protease could be produced via SSF by A. awamori

8 and A. oryzae with temperature of $30{ }^{\circ} \mathrm{C}$. The produced enzymes were utilized to

9 hydrolyze waste bread in the E4. The temperature and agitation speed for enzymatic

10 hydrolysis of waste bread were $55^{\circ} \mathrm{C}$ and $500 \mathrm{rpm}$, respectively. The mixture was then

11 centrifuged in the E5 with $10000 \mathrm{rpm}$ at $4{ }^{\circ} \mathrm{C}$ and filtered to obtain the liquid waste

12 bread hydrolysate and undigested waste bread. The above conditions have been

13 approved to be optimal for SSF and waste bread hydrolysis (Han et al., 2015a). The

14 hydrolysis efficiency from starch to glucose was $61.4 \%$. The produced waste bread

15 hydrolysate, which was rich in glucose and free amino acid, was diluted with tap water

16 in the E6 to get the optimal chemical oxygen demand (COD) concentration for

17 biohydrogen production (Han et al., 2016). The anaerobic sludge used for biohydrogen

18 production was collected and stored in the E10 and heat pretreated in the E8 at $100{ }^{\circ} \mathrm{C}$

19 to inhibit the activity of $\mathrm{CH}_{4}$-producing microorganism. In order to save the energy loss, 
1 the heat exchangers (E9) were arranged in the $\mathrm{H}_{2}$-producing plant. The pretreated

2 sludge was inoculated into the E7 with waste bread hydrolysate to produce the biogas

3 which was purified in the $\mathrm{E} 11$ to get $\mathrm{H}_{2}$ and $\mathrm{CO}_{2}$.

4 The treating capacity of the $\mathrm{H}_{2}$-producing plant was assumed to be 2 ton waste bread

5 per day with lifetime of 10 years. As the glucose yield obtained from the waste bread

6 hydrolysate was $0.277 \mathrm{~g}$ glucose/g waste bread (Han et al., 2016b), it could be

7 calculated that the glucose production was $554 \mathrm{~kg} /$ day. The glucose utilization derived

8 from waste bread hydrolysate was $84.5 \%$. The $\mathrm{H}_{2}$ and $\mathrm{CO}_{2}$ contents in the produced

9 biogas were $37.6 \%$ and $59.8 \%$, respectively. The highest hydrogen production rate in

10 the CSTR was achieved at COD of $6000 \mathrm{mg} / \mathrm{L}$ and HRT of $6 \mathrm{~h}$. So, the capacity of the

$11 \mathrm{H}_{2}$-producing plant (CSTR) could not be smaller than $58.8 \mathrm{~m}^{3}$. Aspen Plus was used in

12 this study to simulate the mass and energy balance of the $\mathrm{H}_{2}$-producing plant.

$14 \quad 2.2$ Total capital investment

15 The total capital investment (TCI) of the $\mathrm{H}_{2}$-producing plant was dependent on fixed

16 capital cost (FCC) and working capital cost (WCC). As a new plant, the FCC included

17 the land cost, equipments cost and installation cost. The land cost could not be

18 considered since the $\mathrm{H}_{2}$-producing plant was built for waste-recycle and the local

19 government would provide the space for free (Lam et al., 2014). The main equipments 
1 used for biohydrogen production were indicated in the Fig. 1. The quantities of the

2 equipments were simulated by mass and energy balance using Aspen Plus and the

3 quotations of the equipments were supplied by the local machine factory. In addition to

4 the equipments cost, the installation cost for building up the $\mathrm{H}_{2}$-producing plant was

5 taken into account. The WCC was considered to be $6.5 \%$ of the FCC (Urbaniec and

6 Grabarczyk, 2014). So, according to the Eq. (1), the TCI of the $\mathrm{H}_{2}$-producing plant

7 could be calculated.

$8 \quad \mathrm{TCI}=\mathrm{FCC}($ Equipments cost + Installation cost $)+\mathrm{WCC}$

$10 \quad 2.3$ Total annual production cost

11 The total annual production cost (TAPC) included the raw materials cost, operators cost,

12 utilities cost, waste treatment cost, maintenance and insurance. As the $\mathrm{H}_{2}$-producing

13 plant was a waste-recycle project, the government was responsible for the collection and

14 transportation of waste bread (Lam et al., 2014). In this case, the raw materials used for

15 biohydrogen production were only fungi and chemicals. The quantity of the fungi (A.

16 awamori and A. oryzae) and chemicals were simulated by Aspen Plus and their unit

17 prices were provided by the local chemical company. Operators cost was the charge for

18 hiring the operators with the average salary of USD3000/year. It was required 6 staffs to

19 operate the $\mathrm{H}_{2}$-producing plant. The waste treatment cost could not be considered 
1 because the liquid waste produced from the $\mathrm{H}_{2}$-producing plant (mainly ethanol, acetate

2 and butyrate) could be used for further biomethane production and the solid waste

3 (mainly undigested waste bread) could be utilized to feed animal. The maintenance and

4 insurance of the plant were assumed to be $1 \%$ and $2 \%$ of the $\mathrm{FCC}$, respectively

5 (Ljunggren and Zacchi, 2010). So, the TAPC for the $\mathrm{H}_{2}$-producing plant could be

6 calculated (Eq. (2)).

$7 \quad$ TAPC $=$ Raw material cost + Utilities cost + Labour cost + Maintenance + Insurance (2)

8 The unit hydrogen production cost (per cubic meter or kilogram) was estimated based

9 on Eq. (3).

10 Unit hydrogen production cost $=\left(\mathrm{TCI} / \mathrm{L}_{\mathrm{T}}+\mathrm{TAPC}-\mathrm{R}_{\mathrm{EH}}\right) / \mathrm{P}_{\mathrm{H}}$

11 where $\mathrm{L}_{\mathrm{T}}$ was the lifetime of the $\mathrm{H}_{2}$-producing plant, $\mathrm{R}_{\mathrm{EH}}$ was the revenue excluding

12 hydrogen and $\mathrm{P}_{\mathrm{H}}$ was the cubic meter or kilogram of produced hydrogen.

$14 \quad 2.4$ Total annual profit

15 The total annual profit (TAP) was the annual revenue minus total annual production cost.

16 The annual revenue of the $\mathrm{H}_{2}$-producing plant was originated from the sales of $\mathrm{H}_{2}\left(\mathrm{~S}_{\mathrm{H}}\right)$,

$17 \mathrm{CO}_{2}\left(\mathrm{~S}_{\mathrm{CD}}\right)$ and undigested waste bread $\left(\mathrm{S}_{\mathrm{UFW}}\right)$ and the charge for waste bread treatment

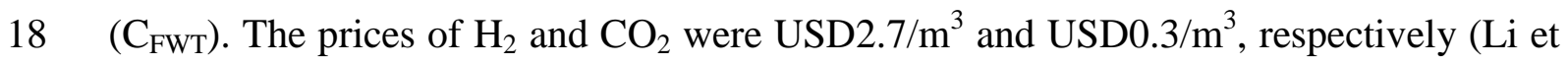

19 al., 2012). Undigested waste bread could be utilized to feed animal (fish feed) with price 
1 of USD0.15/kg (Lam et al., 2014). The waste bread producers need to pay the charge of

2 waste bread treatment (USD16.11/ton waste bread). So, the annual revenue and total

3 annual profit of the $\mathrm{H}_{2}$-producing plant could be calculated according to Eq. (4) and Eq.

$4 \quad(5)$

$5 \quad$ Annual revenue $=\mathrm{S}_{\mathrm{H}}+\mathrm{S}_{\mathrm{CD}}+\mathrm{S}_{\mathrm{UFW}}+\mathrm{C}_{\mathrm{FWT}}$

$6 \quad$ Total annual profit $=$ Annual revenue - Total annual production cost

\section{3. Results and discussion}

93.1 Analysis of total capital investment (TCI) of the $\mathrm{H}_{2}$-producing plant

10 The TCI of the $\mathrm{H}_{2}$-producing plant included the FCC (equipment cost and installation

11 cost) and WCC (Eq. (1)). The equipment cost was dependent on the quantity of the

12 major equipments used for biohydrogen production. Table 1 presented the equipments

13 cost which was USD408200 in total. Table 2 summarized the installation cost for

14 building up the $\mathrm{H}_{2}$-producing plant. According to the equipments cost (Table 1) and

15 installation cost (Table 2), the FCC of USD874200 could be estimated. WCC, which

16 was considered to be $6.5 \%$ of the FCC (Urbaniec and Grabarczyk, 2014), was

17 USD56820. Therefore, the TCI for the $\mathrm{H}_{2}$-producing plant was USD931020. As shown

18 in Fig. 2, the largest part of the TCI was installation cost (50\%) which indicated that

19 installation cost was the main constraint for set-up of $\mathrm{H}_{2}$-producing plant. 
23.2 Analysis of total annual production cost (TAPC) of the $\mathrm{H}_{2}$-producing plant

3 The total annual production cost (TAPC), which included the raw material cost, utilities

4 cost, labour cost, maintenance and insurance, were shown in Table 3. The quantity of

5 the raw material (fungi, $\mathrm{NaHCO}_{3}$ and $\mathrm{H}_{2} \mathrm{SO}_{4}$ ) and utilities (electricity and process water)

6 used for the operation of $\mathrm{H}_{2}$-producing plant was simulated by Aspen Plus. According to

7 the local unit price of chemicals, electricity and process water, the raw material cost

8 (USD19120/year) and utilities cost (USD74400/year) could be calculated, respectively.

9 The total employees for operating the $\mathrm{H}_{2}$-producing plant were 6 with average annual

10 salary of USD30000/employee. So, the operators cost of $\mathrm{H}_{2}$-producing plant was

11 USD180000/year. The maintenance and insurance, which were $2 \%$ and $1 \%$ of the FCC

12 (Ljunggren and Zacchi, 2010), were USD17484/year and USD8742/year, respectively.

13 Therefore, the TAPC of USD299746/year could be calculated according to Eq. (2). Fig.

143 showed the percentage of TAPC of the $\mathrm{H}_{2}$-producing plant. The largest part of the

15 TAPC was the operators cost $(60 \%)$. So, it could be concluded that reducing the

16 quantity of employee (or improve the automatic technology for operating the plant) was

17 the most important parameter for realize biohydrogen production from waste bread in

18 industrial application. 
13.3 Analysis of total annual profit and unit hydrogen production cost of the

$2 \quad \mathrm{H}_{2}$-producing plant

3 The annual revenue of the $\mathrm{H}_{2}$-producing plant was originated from the sales of $\mathrm{H}_{2}\left(\mathrm{~S}_{\mathrm{H}}\right)$,

$4 \quad \mathrm{CO}_{2}\left(\mathrm{~S}_{\mathrm{CD}}\right)$ and undigested waste bread $\left(\mathrm{S}_{\mathrm{UFW}}\right)$ and the charges for waste bread treatment

$5 \quad\left(\mathrm{C}_{\mathrm{FWT}}\right)$ (Table 4). The highest hydrogen production rate and carbon dioxide production

6 rate of CSTR were $353.9 \mathrm{ml} / \mathrm{h} / 1 \mathrm{H}_{2}$ and $530.8 \mathrm{ml} / \mathrm{h} / 1 \mathrm{CO}_{2}$, respectively (Han et al.,

7 2016b). So, the annual yield of $\mathrm{H}_{2}$ and $\mathrm{CO}_{2}$ were $182060 \mathrm{~m}^{3} \mathrm{H}_{2}$ and $273080 \mathrm{~m}^{3} \mathrm{CO}_{2}$,

8 respectively. It could be calculated that the annual revenue from sales of $\mathrm{H}_{2}$ and $\mathrm{CO}_{2}$

9 were USD491560/year and USD81920/year, respectively. The $\mathrm{S}_{\mathrm{UFW}}$ could be utilized to

10 feed animal with revenue of USD54760/year. According to the annual quantity of

11 treated waste bread (730 ton) and unit price for waste bread treatment (USD16/ton), the

$12 \mathrm{C}_{\mathrm{FWT}}$ of USD11680/year could be calculated. Therefore, the annual revenue of the

$13 \mathrm{H}_{2}$-producing plant was USD639920/year. As the total annual production cost was

14 USD299746/year, the total annual profit of USD244186/year could be calculated. Fig. 4

15 showed the percentage of annual revenue of the $\mathrm{H}_{2}$-producing plant. It was observed

16 that the revenue from sale of $\mathrm{H}_{2}(76.8 \%)$ occupied the most important part of the annual

17 revenue. So, the hydrogen yield and hydrogen market price played a crucial role for

18 realizing biohydrogen production in industrial scale.

19 According to Eq. (3), the unit hydrogen production cost of the plant was USD1.34/m 3 
$1 \mathrm{H}_{2}$ (or USD14.89/kg $\mathrm{H}_{2}$ ). The current unit hydrogen production costs from other

2 technologies were shown in Table 5. It was observed that the steam methane reforming

3 was the most competitive way in term of the unit hydrogen production cost since it had

4 been developed and industrialized for a long period. Water electrolysis seemed to be

5 more attractive than other technologies, but it needed to consume electricity power to

6 release hydrogen from water. Although the obtained unit hydrogen production cost

7 could not compete with other reported ways at the present time, it was still much

8 cheaper than the hydrogen market unit price (USD2.7/ $\mathrm{m}^{3}$ ). Furthermore, biohydrogen

9 production from waste bread could be a promising and sustainable technology in the

10 future because it could use renewable substrate (waste bread) for hydrogen production.

11 The potential benefits obtained by biohydrogen production from waste bread are much

12 more meaningful than other technologies.

143.4 Profitability criteria of the $\mathrm{H}_{2}$-producing plant

15 Fig. 5 (a) showed the net present value (NPV) and payback period (PP) of the

$16 \mathrm{H}_{2}$-producing plant with different discount rate. Obviously, the NPV increased and PP

17 decreased with the discount rate decreased from $30 \%$ to 0 which indicated that the

$18 \mathrm{H}_{2}$-producing plant was more attractive with lower discount rate. The optimal NPV of

19 USD1266654 and PP of 4.8 years were obtained at discount rate of 0. Fig. 5 (b) 
1 described the internal rate of return (IRR) of the $\mathrm{H}_{2}$-producing plant from waste bread.

2 It was observed that IRR was $21.77 \%$ with the NPV was equal to 0 . The positive IRR

3 indicated the attractiveness of the hydrogen-producing plant. Therefore, it was found

4 that the $\mathrm{H}_{2}$-producing plant was feasible for industrial application.

5 In order to examine the effects of the economic variables on the performance of the

$6 \mathrm{H}_{2}$-producing plant, the sensitivity analysis was carried out in this study. Fig. 6 (a)

7 indicated the sensitivity analysis of the $\mathrm{H}_{2}$-producing plant from waste bread. It was

8 observed that the most important variables on the NPV were hydrogen price and

9 operating labor cost with sensitivity slopes of $y=4 E+06 x+1 E+06$ and $y=-2 E+06 x$

$10+1 \mathrm{E}+06$, respectively (Table 6). Obviously, the hydrogen price and operating labor

11 cost were the largest parts of the annual revenue and total annual production cost,

12 respectively. So, reducing the quantity of operators and improving the automatic

13 technology were the best way to avoid the risk while increasing the hydrogen yield was

14 the most efficient method for realizing hydrogen production for industrial application.

15 Fig. 6 (b) described the annual cost or revenue of the $\mathrm{H}_{2}$-producing plant with the

16 required quantity of the waste bread per day. The fixed costs were assumed to keep

17 unchanged for treating 2 ton waste bread/day. The variable cost, total cost and revenue

18 of the $\mathrm{H}_{2}$-producing plant were direct proportion to the quantity of treated waste bread.

19 It was observed from Fig. 6 (b) that the revenue was bigger than the total cost when the 
1 quantity of treated waste bread was 0.58 ton/day. Therefore, the least required quantity

2 of treated waste bread per day was 0.58 ton and the $\mathrm{H}_{2}$-producing plant began to profit

3 when the quantity of the treated waste bread was higher than that point.

4

\section{4. Conclusions}

6 The feasibility of the biohydrogen production in a continuous stirred tank reactor

7 (CSTR) from waste bread was assessed. The obtained unit hydrogen production cost

8 was USD1.34/ $\mathrm{m}^{3} \mathrm{H}_{2}$ (or USD14.89/ $\mathrm{kg} \mathrm{H}_{2}$ ) which was much cheaper than the hydrogen

9 market unit price $\left(\mathrm{USD} 2.7 / \mathrm{m}^{3}\right)$. The $\mathrm{H}_{2}$-producing plant was more attractive with lower

10 discount rate and began to profit when the quantity of the treated waste bread was

11 higher than 0.58 ton/day. Reducing the quantity of operating labor and improving the

12 automatic technology were the best way to avoid the risk of industrial biohydrogen

13 production.

\section{Acknowledgements}

16 This research was supported by National Science Foundation of China (No. 41373121),

17 Zhejiang Education Department (Y201533249) and Research Foundation from

18 Hangzhou Dianzi University (KYS205613034). 


\section{References}

2 1. Acar, C., Dincer, I., 2015. Impact assessment and efficiency evaluation of hydrogen

3 production methods. Int. J. Energ. Res. 13, 1757-1768.

4 2. Chu, S., Majumdar, A., 2012. Opportunities and challenges for a sustainable energy future. Nature 488, 294-303.

6 3. De Gioannis, G., Muntoni, A., Polettini, A., Pomi, R., 2013. A review of dark

7 fermentative hydrogen production from biodegradable municipal waste fractions.

$8 \quad$ Waste Manage. 33, 1345-1361.

9 4. Dufo-Lopez, R., Bernal-Agustin, L.Z., Mendoza, F., 2009. Design and economical

10 analysis of hybrid PV-wind systems connected to the grid for the intermittent

11 production of hydrogen. Energy Policy 37, 3082-3095.

12 5. Galera, S., Gutierrez-Ortiz, F.J., 2015. Techno-economic assessment of hydrogen and

13 power production from supercritical water reforming of glycerol. Fuel 144, $14 \quad 307-316$.

15 6. Guerrro-Lemus, R., Martinez-Duart, J.M., 2010. Updated hydrogen production costs

16 and parties for conventional and renewable technologies. Int. J. Hydrogen Energy

$17 \quad 35,3929-3936$.

18 7. Han, W., Hu, Y.Y., Li, S.Y., Li, F.F., Tang, J.H., 2016a. Biohydrogen production in the

19 suspended and attached microbial growth systems from waste pastry hydrolysate. 
2 8. Han, W., Huang, J.G., Zhao, H.T., Li, Y.F., 2016b. Continuous biohydrogen production from waste bread by anaerobic sludge. Bioresour. Technol. 212, 1-5.

4 9. Han, W., Lam, W.C., Melikoglu, M., Wong, M.T., Leung, H.T., Ng, C.L., Yan, P., Yeung, S.Y., Lin, C.S.K., 2015a. Kinetic analysis of a crude enzyme extract produced via solid state fermentation of bakery waste. ACS Sustain. Chem. Eng. 3, 2043-2048.

10. Han, W., Ye, M., Zhu, A.J., Zhao, H.T., Li, Y.F., 2015b. Batch dark fermentation from enzymatic hydrolyzed food waste for hydrogen production. Bioresour.

11 11. Hatech, C., Center, A., Feitelberg, A.S., Fisher, E.M., Mutolo, P.F., 2013. Economic analysis of hydrogen production from wastewater and wood for municipal bus system. Int. J. Hydrogen Energy 38, 16002-16010.

12. Kalinci, Y., Hepbasli, A., Dincer, I., 2015. Techno-economic analysis of a stand-alone hybrid renewable energy system with hydrogen production and storage options. Int. J. Hydrogen Energy 40, 7652-7664.

17 13. Kim, D.H., Kim, S.H., Kim, H.W., Kim, M.S., Shin, H.S., 2011. Sewage sludge addition to food waste synergistically enhances hydrogen fermentation performance. Bioresour. Technol. 102, 8501-8506. 
1 14. Kim, D.H., Kim, S.H., Kim, K.Y., Shin, H.S., 2010. Experience of a pilot-scale

2 hydrogen producing anaerobic sequencing batch reactor (ASBR) treating food waste. Int. J. Hydrogen Energy 35, 1590-1594.

4 15. Lam, K.F., Leung, C.C.J., Lei, H.M., Lin, C.S.K., 2014. Economic feasibility of a pilot-scale fermentative succinic acid production from bakery wastes. Food Bioprod. Process. 92, 282-290.

16. Li, Y.C., Liu, Y.F., Chu, C.Y., Chang, P.L., Hsu, C.W., Lin, P.J., Wu, S.Y., 2012. Techno-economic evaluation of biohydrogen production from wastewater and agricultural waste. Int. J. Hydrogen Energy 37, 15704-15710.

17. Ljunggren, M., Zacchi, G., 2010. Techno-economic evaluation of a two-step biological process for hydrogen production. Biotechnol. Prog. 26, 496-504.

18. Logan, B.E., Oh, S., Kim, I.S., Van-Ginkel, S., 2002. Biological $\mathrm{H}_{2}$ production measured in batch anaerobic respirometers. Environ. Sci. Technol. 36, 2530-2535.

19. Show, K.Y., Lee, D.J., Tay, J.H., Lin, C.Y., Chang, J.S., 2012. Biohydrogen production: current perspectives and the way forward. Int. J. Hydrogen Energy 34, 15616-15631.

20. Turner, J. A., 2004. Sustainable Hydrogen Production. Science 305, 972-974. - a techno-economic study. J. Clean. Prod. 65, 324-329. 
1 22. Van-Ginkel, S.W., Oh, S.E., Logan, B.E., 2005. Biohydrogen gas production from

2 food processing and domestic wastewaters. Int. J. Hydrogen Energy 30, 3 $1535-1542$.

4 23. Wake, B., 2012. Energy economics: Biofuel economic potential. Nat. Clim. Chang.

5 2, 394-395.

6 24. Yasin, N.H.M., Mumtaz, T., Hassan, M.A., Rahman, N.A.A., 2013. Food waste and 7 food processing waste for biohydrogen production: A review. J. Environ. Manage. 130, 375-385. 


\section{Figure legends}

2 Table 1 Equipment cost of the $\mathrm{H}_{2}$-producing plant from waste bread.

3 Table 2 Installation cost of the $\mathrm{H}_{2}$-producing plant from waste bread.

4 Table 3 Total annual production cost of the $\mathrm{H}_{2}$-producing plant from waste bread.

5 Table 4 Annual revenue of the $\mathrm{H}_{2}$-producing plant from waste bread.

6 Table 5 Unit hydrogen production costs with different processes.

7 Table 6 Results of sensitivity analysis of the $\mathrm{H}_{2}$-producing plant from waste bread.

8 Fig. 1. The flow of biohydrogen production from waste bread in the CSTR.

9 Fig. 2. The percentage of total capital investment of the $\mathrm{H}_{2}$-producing plant.

10 Fig. 3. The percentage of total annual production cost of the $\mathrm{H}_{2}$-producing plant.

11 Fig. 4. The percentage of annual revenue of the $\mathrm{H}_{2}$-producing plant.

12 Fig. 5. Cumulative cash flow diagram at different discount rates (a) and internal rate of

13 return $(b)$.

14 Fig. 6. Sensitivity analysis (a) and breakeven chart (b) of the $\mathrm{H}_{2}$-producing plant from waste bread. 
1 Table 1 Equipment cost of the $\mathrm{H}_{2}$-producing plant from waste bread.

\begin{tabular}{|c|c|c|c|c|}
\hline Code & Equipment & Specification & Quantity & Cost (USD) \\
\hline E1 & $\begin{array}{c}\text { Waste bread } \\
\text { storage }\end{array}$ & $\begin{array}{c}\text { Working } \\
\text { capacity: } 20 \\
\text { ton }\end{array}$ & 1 & 15000 \\
\hline E2 & $\begin{array}{l}\text { Waste bread } \\
\text { grinding }\end{array}$ & $\begin{array}{l}\text { Working } \\
\text { capacity: } 2 \\
\text { ton } / \mathrm{h}\end{array}$ & 1 & 72000 \\
\hline E3 & $\begin{array}{l}\text { Solid state } \\
\text { fermentation }\end{array}$ & Oil jacket & 2 & 24000 \\
\hline E4 & $\begin{array}{l}\text { Waste bread } \\
\text { hydrolysis }\end{array}$ & $\begin{array}{l}\text { Oil jacket with } \\
\text { stirrer }\end{array}$ & 1 & 46000 \\
\hline E5 & $\begin{array}{c}\text { Centrifuge of } \\
\text { mixture }\end{array}$ & $\begin{array}{c}\text { Working } \\
\text { capacity: } 670 \\
\text { L/h }\end{array}$ & 1 & 28200 \\
\hline E6 & $\begin{array}{l}\text { Waste bread } \\
\text { hydrolysate } \\
\text { tank }\end{array}$ & & 1 & 15000 \\
\hline E7 & CSTR & $\begin{array}{c}\text { Working } \\
\text { volume: } 29.4 \\
\mathrm{~m}^{3}\end{array}$ & 2 & 55000 \\
\hline E8 & $\begin{array}{l}\text { Sludge heat } \\
\text { pretreated } \\
\text { equipment }\end{array}$ & $\begin{array}{l}100^{\circ} \mathrm{C} \\
\text { thermostatic } \\
\text { control }\end{array}$ & 1 & 30000 \\
\hline E9 & $\begin{array}{c}\text { Heat } \\
\text { exchanger }\end{array}$ & $\begin{array}{c}\text { Heat } \\
\text { exchanger }\end{array}$ & 3 & 45000 \\
\hline E10 & Sludge storage & $100^{\circ} \mathrm{C}$ & 1 & 15000 \\
\hline E11 & $\begin{array}{l}\text { Biogas } \\
\text { purified } \\
\text { system }\end{array}$ & $\begin{array}{l}\text { Separation of } \\
\text { produced } \\
\text { biogas }\end{array}$ & 1 & 63000 \\
\hline Total & - & - & - & 408200 \\
\hline
\end{tabular}

2 
1 Table 2 Installation cost of the $\mathrm{H}_{2}$-producing plant from waste bread.

\begin{tabular}{cccc}
\hline Item & Cost (USD) & Item & Cost (USD) \\
Installation & 68000 & Instrumentation & 17200 \\
Piping & 40800 & Supervision & 40800 \\
Electrical systems & 27200 & Construction & 54400 \\
& & expenses & 13600 \\
Buildings & 68000 & Legal expenses & \\
Service facilities & 34000 & Contractor's fee & 20400 \\
Yard improvements & 13600 & Contingency & 68000 \\
Total & - & - & 466000
\end{tabular}

2

3

4

5

6

7

8

9 
1 Table 3 Total annual production cost of the $\mathrm{H}_{2}$-producing plant from waste bread.

\begin{tabular}{|c|c|c|c|c|}
\hline & Component & Unit price (USD) & Quantity & Cost \\
\hline Raw materials cost & A. awamori & $6.3 / \mathrm{kg}$ & 200 & 1260 \\
\hline \multicolumn{5}{|l|}{ (Chemicals) } \\
\hline & A. oryzae & $37.6 / \mathrm{kg}$ & 200 & 7520 \\
\hline & $\mathrm{NaHCO}_{3}$ & $10 /$ ton & 950 & 9500 \\
\hline & $\mathrm{H}_{2} \mathrm{SO}_{4}$ & $4 /$ ton & 210 & 840 \\
\hline \multirow[t]{2}{*}{ Utilities cost } & Electricity & $0.084 / \mathrm{kWh}$ & 600000 & 50400 \\
\hline & Process water & $0.1 / \mathrm{m}^{3}$ & 240000 & 24000 \\
\hline Labor cost & - & 30000/employee & 6 & 180000 \\
\hline Maintenance & - & $2 \%$ of FCC & - & 17484 \\
\hline Insurance & - & $1 \%$ of FCC & - & 8742 \\
\hline Total & - & - & - & 299746 \\
\hline
\end{tabular}

2

3

4

5

6 
1 Table 4 Annual revenue of the $\mathrm{H}_{2}$-producing plant from waste bread.

\begin{tabular}{|c|c|c|c|}
\hline Product & Quantity & Unit price (USD) & Revenue \\
\hline & & & (USD/year) \\
\hline $\mathrm{H}_{2}$ & $182060 \mathrm{~m}^{3}$ & 2.7 & 491560 \\
\hline $\mathrm{CO}_{2}$ & $273080 \mathrm{~m}^{3}$ & 0.3 & 81920 \\
\hline Solid biomass (fish & 365 ton & 150 & 54760 \\
\hline \multicolumn{4}{|l|}{ feed) } \\
\hline Waste bread & 730 ton & 16 & 11680 \\
\hline \multicolumn{4}{|l|}{ treatment } \\
\hline Annual revenue & - & - & $639920(543932)$ \\
\hline \multicolumn{4}{|l|}{ (after tax) } \\
\hline Total annual & - & - & 299746 \\
\hline \multicolumn{4}{|l|}{ production cost } \\
\hline Total annual profit & - & - & 244186 \\
\hline
\end{tabular}

2

3

4

5

6 
1 Table 5 Unit hydrogen production costs with different processes.

\begin{tabular}{|c|c|c|}
\hline Processes & $\begin{array}{c}\text { Unit } \mathrm{H}_{2} \text { production price } \\
\left(\mathrm{USD} / \mathrm{kg} \mathrm{H}_{2}\right)\end{array}$ & References \\
\hline Steam methane reforming & $4-5$ & Hatech et al., 2013 \\
\hline Water electrolysis & $8.4-12.2$ & Yasin et al., 2013 \\
\hline \multirow[t]{2}{*}{ Hydropower electrolysis } & $5.4-7.9$ & Guerrro-Lemus and \\
\hline & & Martinez-Duart, 2010 \\
\hline Supercritical water & 5.36 & Galera and \\
\hline reforming of glycerol & & Gutierrez-Ortiz, 2015 \\
\hline Solar thermochemical & $6.7-11.6$ & Guerrro-Lemus and \\
\hline cycle & & Martinez-Duart, 2010 \\
\hline Hybrid PV-wind & $12-13$ & Dufo-Lopez et al., 2009 \\
\hline \multicolumn{3}{|l|}{ (photovoltaic-wind) } \\
\hline Biohydrogen production & 14.9 & This study \\
\hline from waste bread & & \\
\hline
\end{tabular}

2

3

4 
1 Table 6 Results of sensitivity analysis of the $\mathrm{H}_{2}$-producing plant from waste bread.

\begin{tabular}{cc}
\hline Item & Sensitivity slopes \\
\hline $\mathrm{H}_{2}$ price & $4 \mathrm{E}+06 \mathrm{x}+1 \mathrm{E}+06$ \\
$\mathrm{CO}_{2}$ price & $737280 \mathrm{x}+1 \mathrm{E}+06$ \\
Solid biomass & $492840 \mathrm{x}+1 \mathrm{E}+06$ \\
Operators cost & $-2 \mathrm{E}+06 \mathrm{x}+1 \mathrm{E}+06$ \\
Utilities cost & $-669600 \mathrm{x}+1 \mathrm{E}+06$ \\
& $-172080 \mathrm{x}+1 \mathrm{E}+06$ \\
\hline
\end{tabular}

2

3

4 


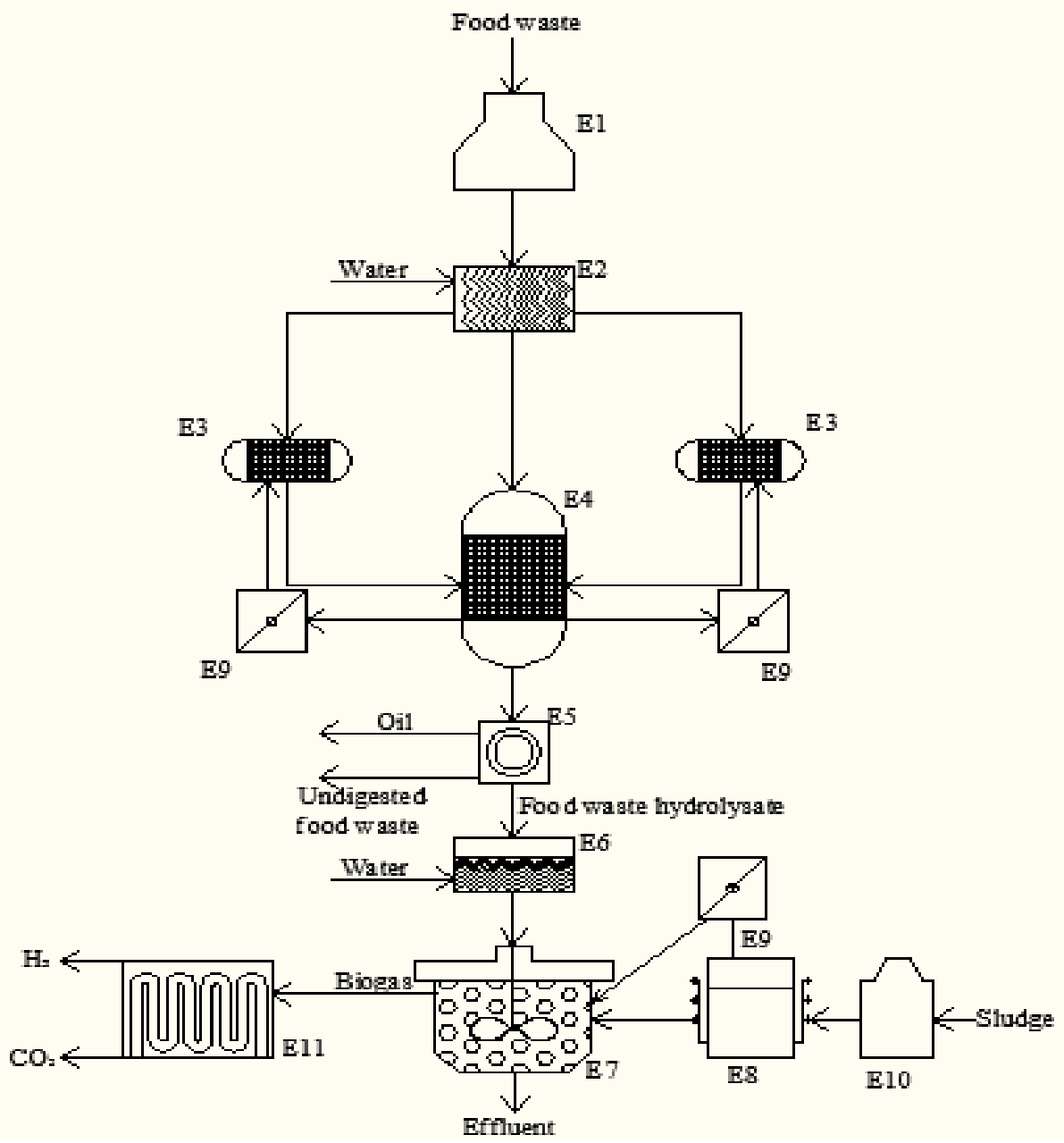

2 Fig. 1. The flow of biohydrogen production from waste bread in the CSTR. (E1: waste

3 bread storage; E2: waste bread grinding; E3: solid state fermentation; E4: waste bread

4 hydrolysis; E5: centrifuge of the mixture; E6: waste bread hydrolysate tank; E7: CSTR;

5 E8: sludge heat pretreated equipment; E9: heat exchanger; E10: sludge storage)

6

7

8 


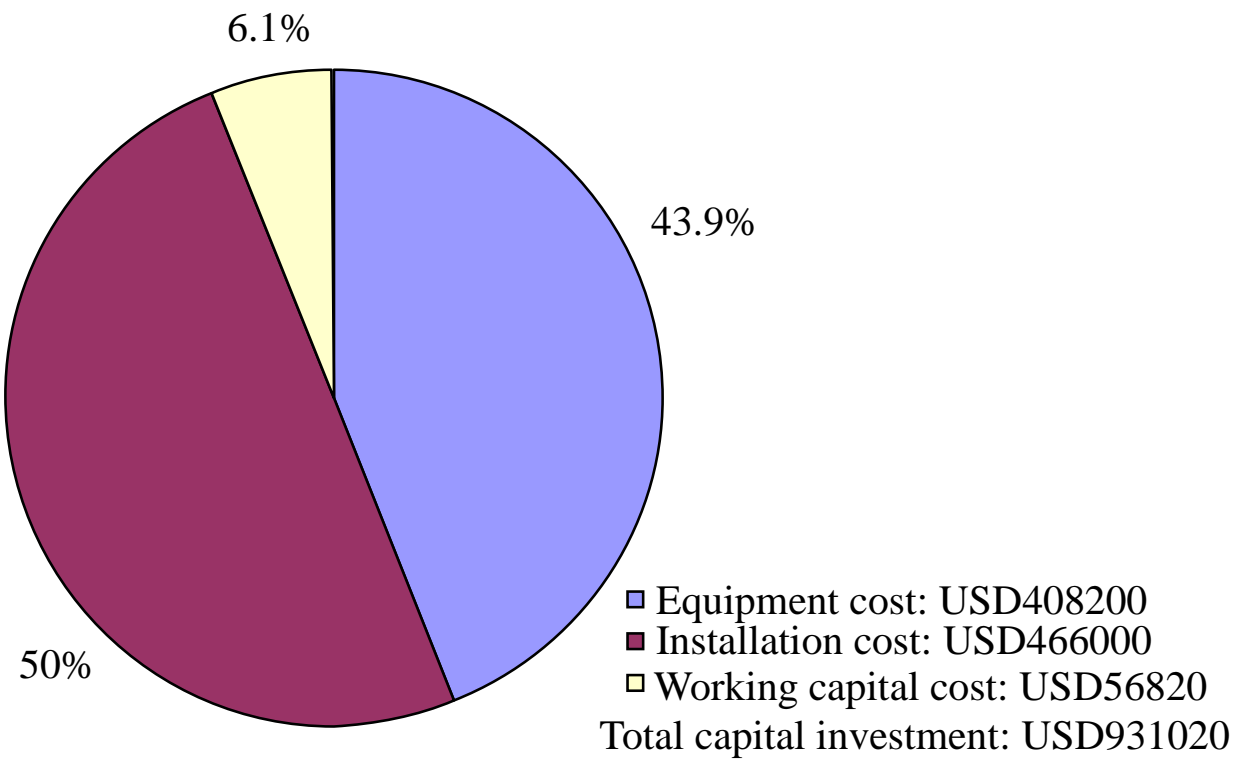

2

Fig. 2. The percentage of total capital investment of the $\mathrm{H}_{2}$-producing plant. 


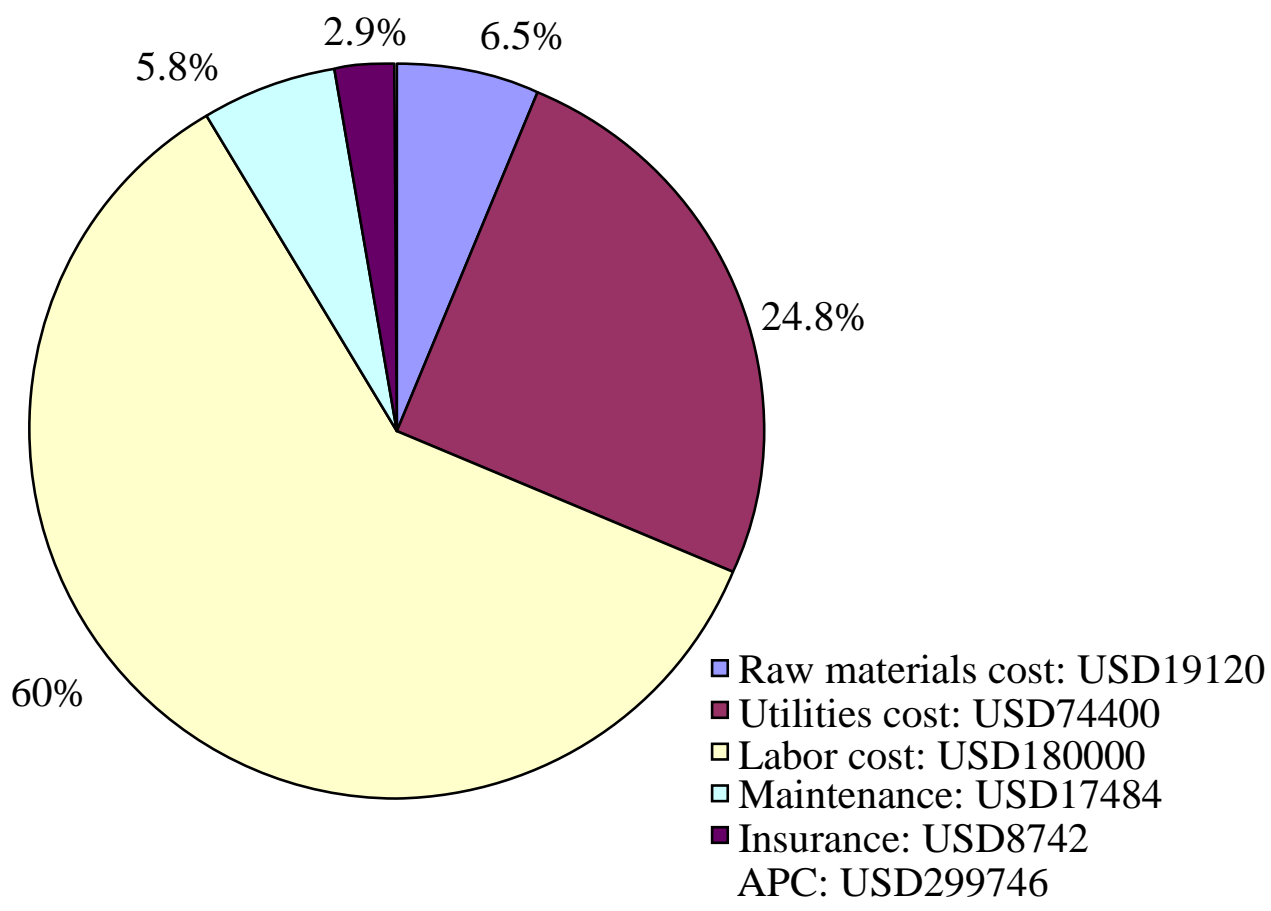

2 Fig. 3. The percentage of total annual production cost of the $\mathrm{H}_{2}$-producing plant. 


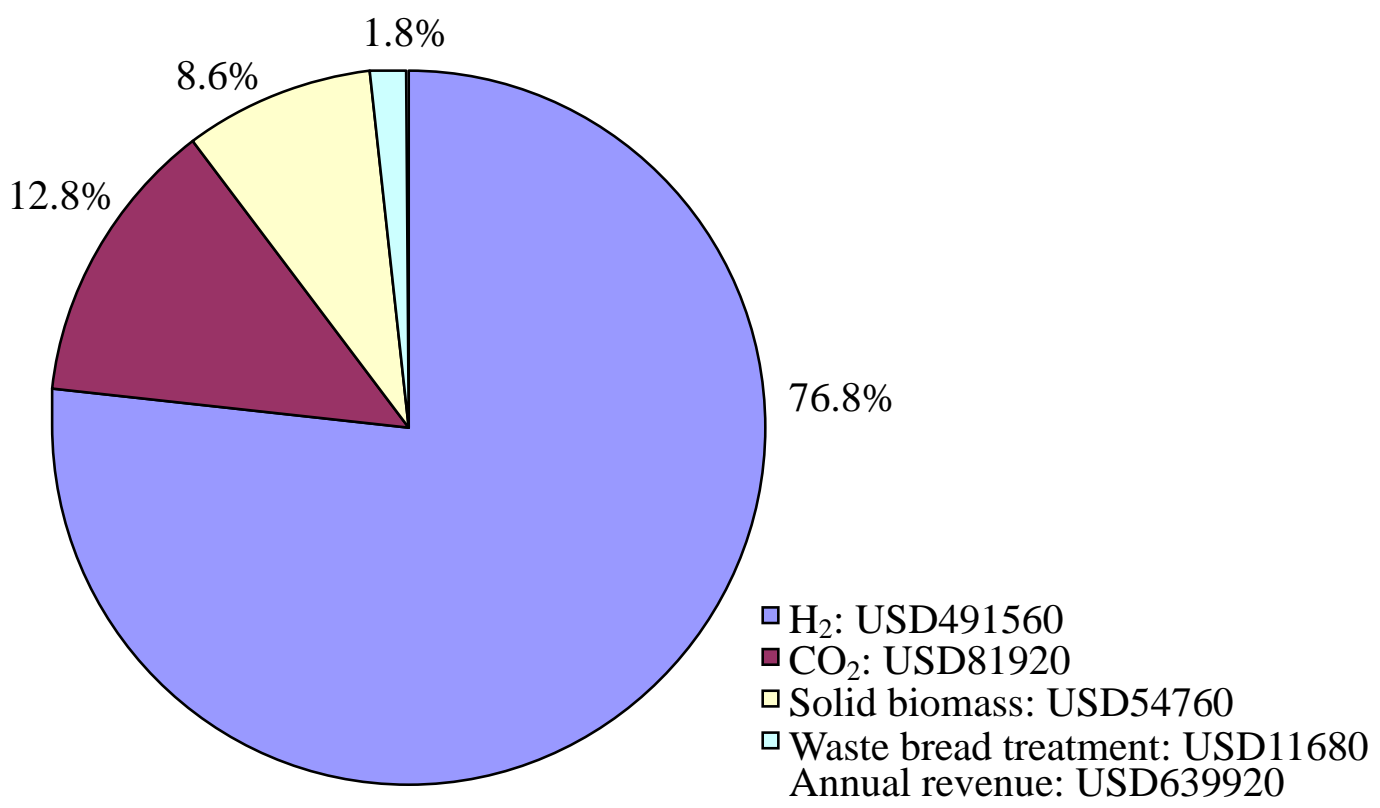

Fig. 4. The percentage of annual revenue of the $\mathrm{H}_{2}$-producing plant. 


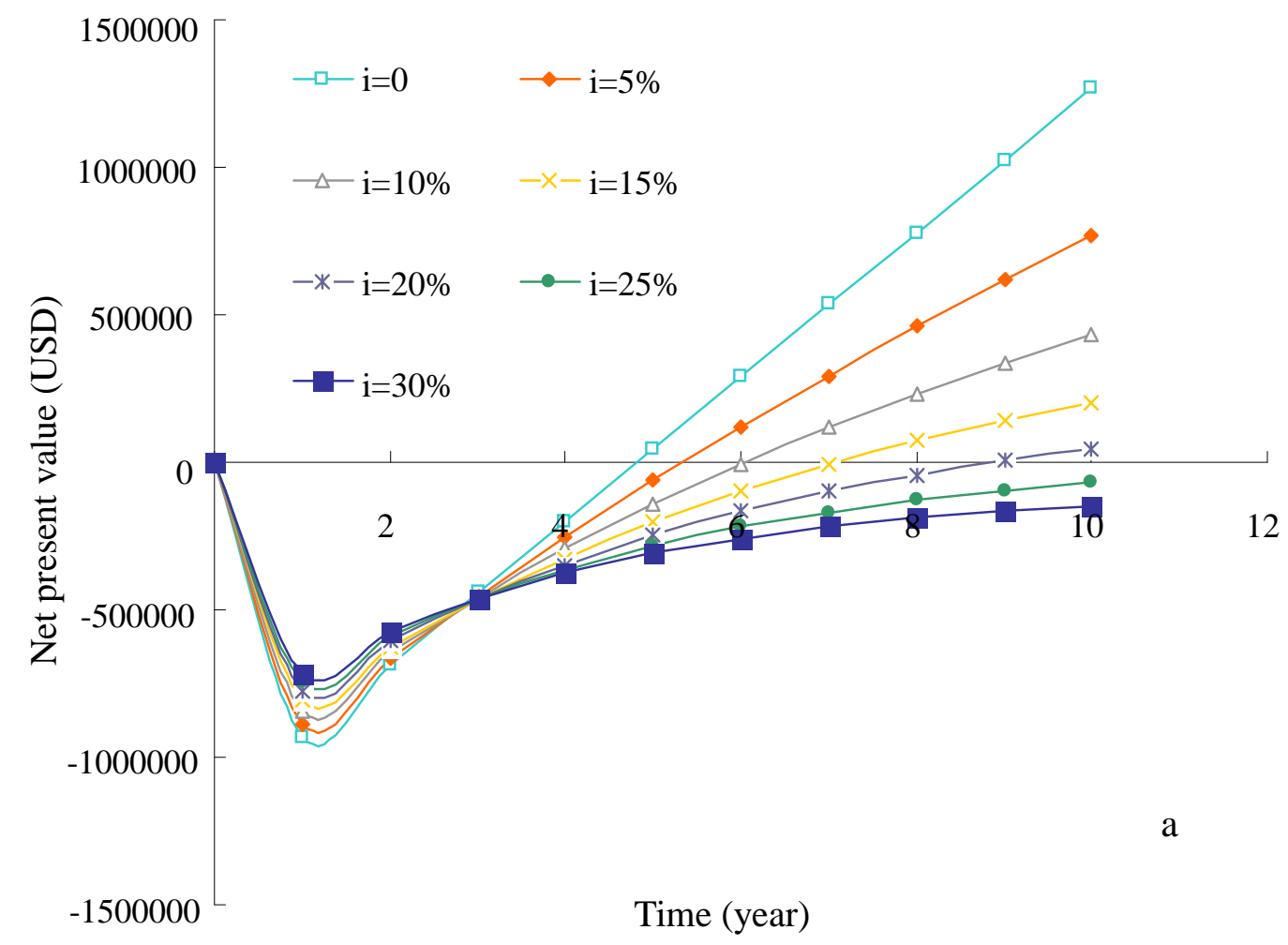

1

2

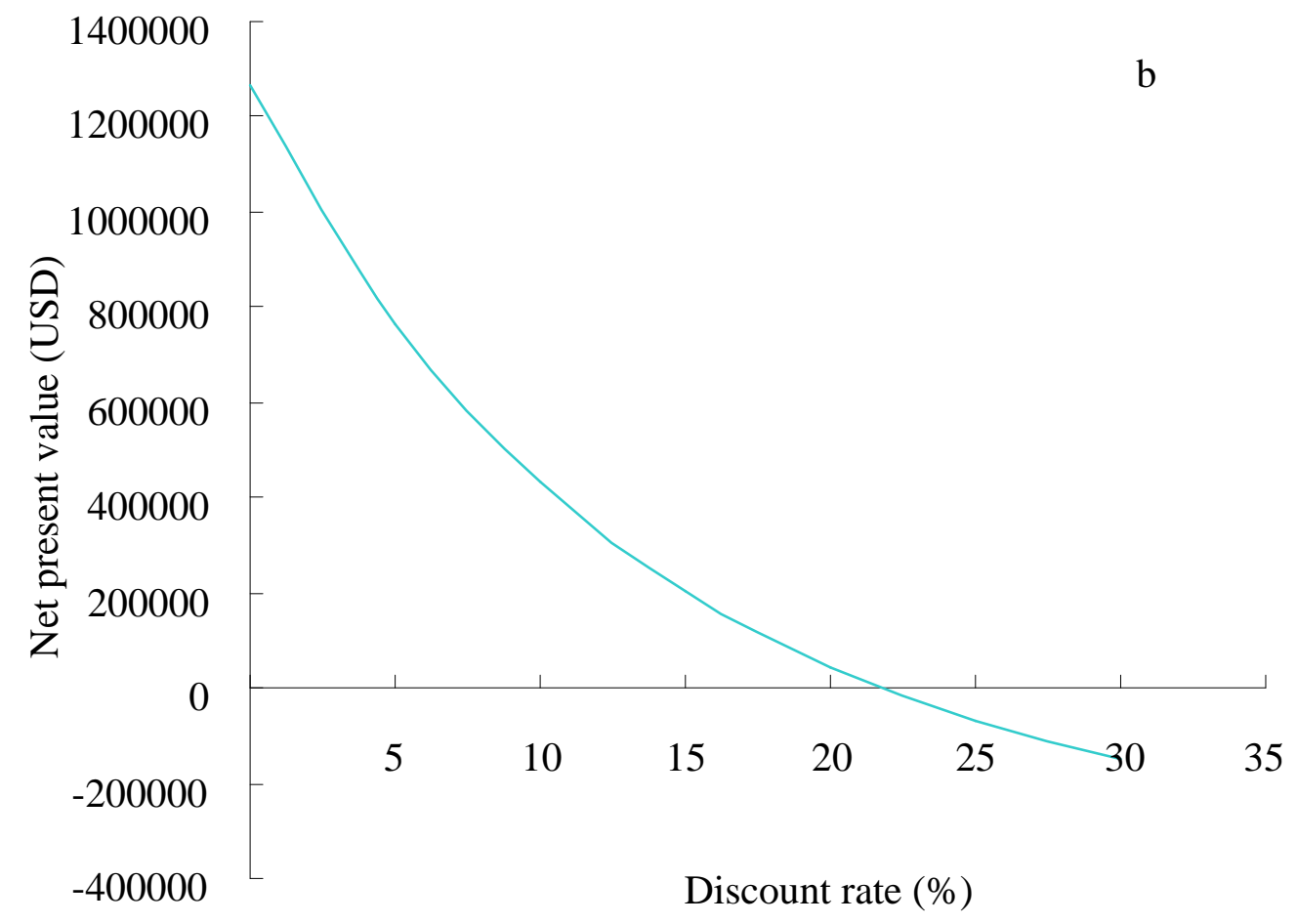

3 Fig. 5. Cumulative cash flow diagram at different discount rates (a) and internal rate of

return (b). 


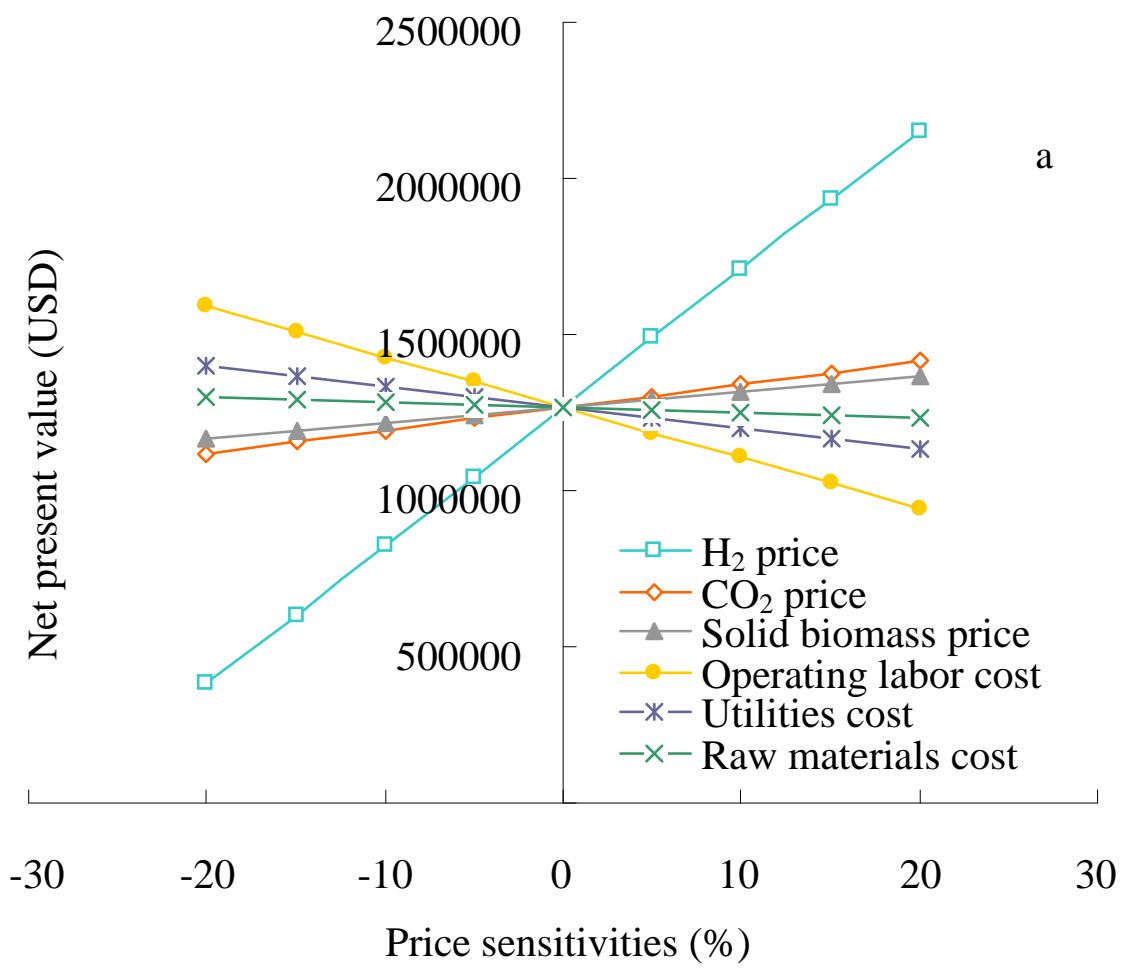

1

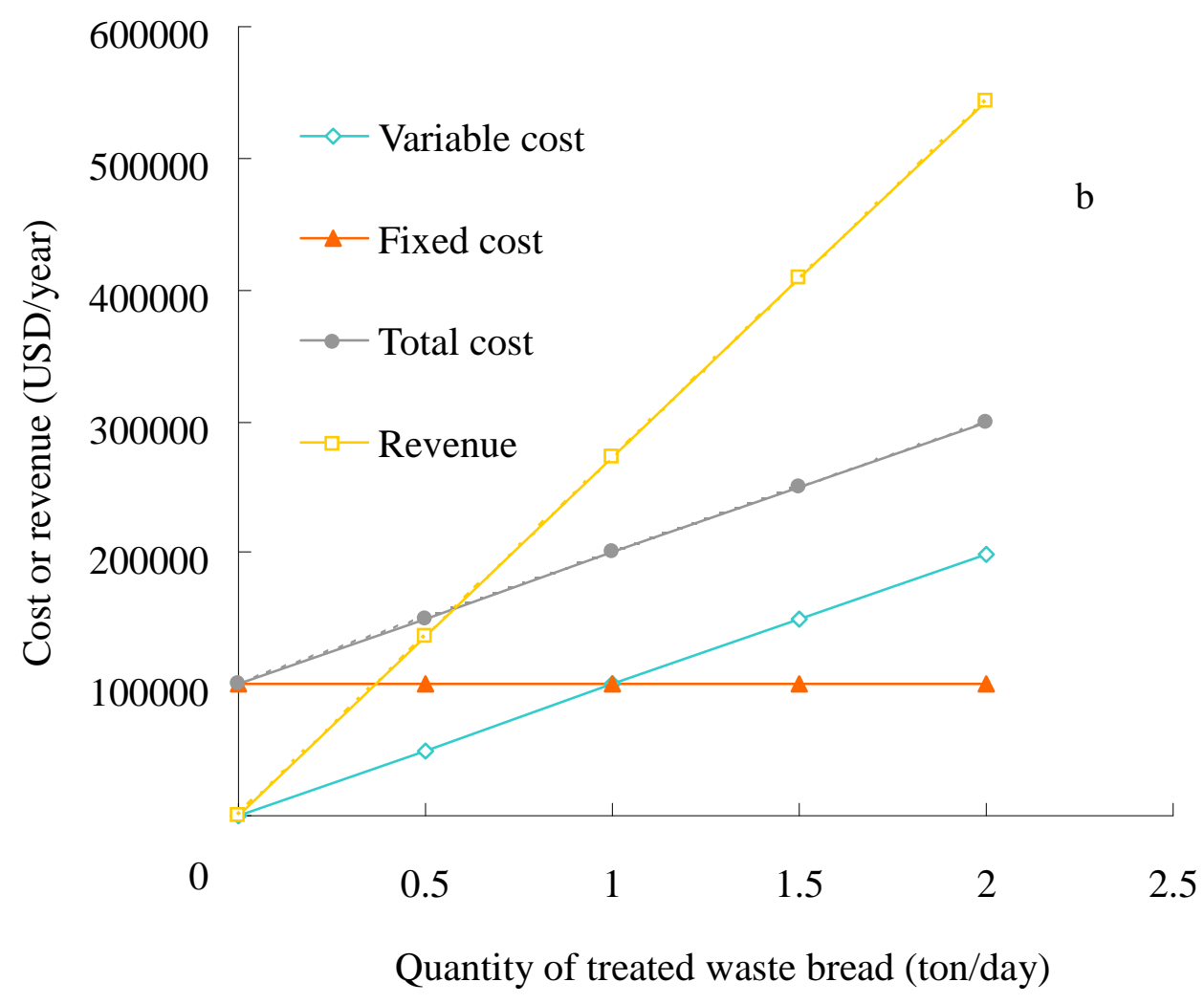

3 Fig. 6. Sensitivity analysis (a) and breakeven chart (b) of the $\mathrm{H}_{2}$-producing plant from 